\title{
Sustainability in Small and Medium-Sized Manufacturing Enterprises: An Empirical Study
}

\author{
I. Garbie
}

\begin{abstract}
Department of Mechanical and Industrial Engineering, Sultan Qaboos University, Muscat, Sultanate of Oman
\end{abstract} Department of Mechanical Engineering, Helwan University, Helwan, Cairo, Egypt

Received 21 January 2015; Accepted 10 April 2015

\begin{abstract}
The main goal of this paper is to analyze and investigate sustainable practices in small and medium-sized manufacturing enterprises (SMEs). A comprehensive analysis and a mathematical framework are used to assess the sustainability indexes (SDIs) of each aspect/issue and pillar/dimension, and of the whole manufacturing enterprise. Sustainability in the whole manufacturing enterprise is represented by the sustainable development index (SDI). The results show that there is a significant difference in SDIs between aspects and dimensions, with economic sustainability representing the highest percentage in the SDI. Also, the results show that industrial companies are adopting sustainable practices and applying them to most of the issues/aspects of the dimensions, and they can direct manufacturing companies in the industrial sector to develop strategies for sustainability. This paper introduces a new understanding of the practices and implementation of sustainability/sustainable development by SMEs through assessing the SDIs.
\end{abstract}

Keywords: Sustainability, Sustainable development, Manufacturing enterprises.

$$
\begin{aligned}
& \text { الاستدامة ِِ المشروعات الصناعية الصغيرة والمتوسطة- دراسة تجريبية } \\
& \text { إبراهيم جرابيع } \\
& \text { الملخص: إن الهدف الأساسي من هذه الورقة هو التحليل والتحقق من ممارسات الإستدامة يِّ المشاريع الصناعية الصغيرة }
\end{aligned}
$$

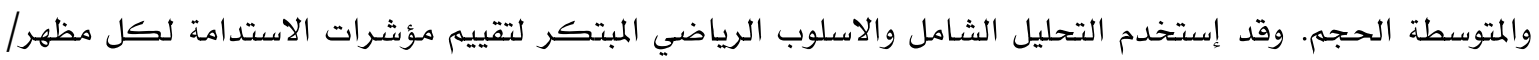

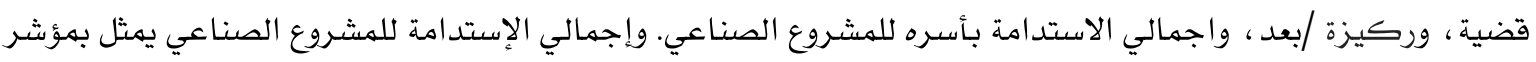

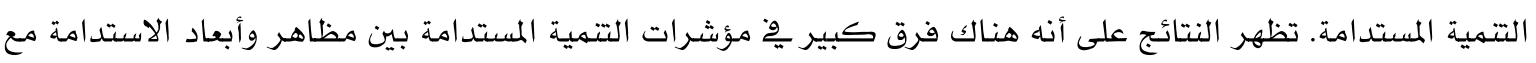

$$
\begin{aligned}
& \text { إعتبار الإستدامة الاقتصادية الأعلى نسبيا خلال مؤشر الاستدامة. وكذلك تشير النتائج إلى أن الشركات الصناعية سوف }
\end{aligned}
$$

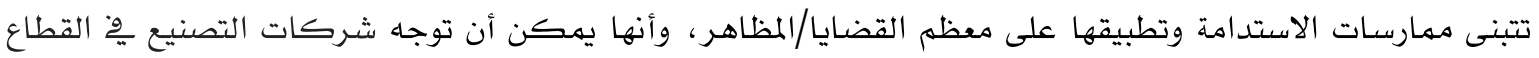

$$
\begin{aligned}
& \text { الصناعي لتطوير إستراتيجيات الإستدامة. يقدم هذا البحث مفهوم جديد للممارسات وتطبيق الاستدامة/التتمية المستدامة } \\
& \text { وِّ المشروعات الصناعية الصغيرة والمتوسطة الحجم من خلال تقييم مؤشرات الاستدامة. } \\
& \text { الكلمات المفتاحية: الاستدامة ، التتمية المستدامة ، المشروعات الصناعية. }
\end{aligned}
$$

*Corresponding author's e-mail: garbie@squ.edu.om 


\section{Introduction}

The World Commission on Environment and Development (WCED) defined sustainability as development that meets the needs of the present without affecting the ability of future generations to meet their own needs (1987). Sustainability/sustainable development (SD) is based on and is used to balance between three dimensions: economy, society, and environment. To achieve sustainability for the survival of productivity and a community's well-being, some manufacturing enterprises must change their products or manufacturing processes which are related to events and processes outside their direct control, including their supply chains and the standard measure of sustainability performance. The environmental impact can be reduced through end of life product management, and a green design should be introduced with a manufacturing process that requires little energy and emits zero waste. To extend product life, preventive maintenance should be employed.

Small and medium-sized manufacturing enterprises (SMEs) are considered pivotal to growth and development, especially in developing countries (Urban and Naidoo 2012). SMEs are poised to solve socio-economic problems in developing countries as the manufacturing sector is one of the most significant contributors to gross domestic product (GDP), in spite of the fact that SMEs are characterized and challenged by uncertain markets and high failure rates. On the other side of the economic spectrum, developed countries such as the USA have markets that are dominated by SMEs with fewer than 500 employees (Theyel and Hofmann 2012). Therefore, analysis and investigation of SD in SMEs is very important and should be appreciated.

SD always emphasizes the satisfaction of people's basic need so that they may enjoy a better quality of life (QOL) without compromising the QOL of future generations (WCED, 1987). SD means making decisions that integrate and incorporate the main dimensions of sustainability and is important and urgent as the recognition of its value is fundamental to implementing sustainable practices, especially in SMEs. SD has a lot of drivers and barriers (Kulatunga et al. 2013). The drivers, or motivational factors, are numerous and represented by risk reduction, pressure from the market (customer demand), its potential to be used as a marketing tool (ISO certification), government regulation (eg. legislation), limitations in the existing process improvement techniques, success stories of sustainable manufacturing in other organizations, economic benefits, and the availability of funds for green projects.

Implementing these drivers will reduce the possible risks of the SMEs and increase their positive reputations, resulting in a positive relationship with stakeholders and an increase in customer loyalty and, consequently, economic growth. The SMEs should be developed through product and process innovations, and increased market share and motivation of employees, with a simultaneous reduction in material and water consumption, and scrape rates. SMEs also face barriers such as the lack of awareness of sustainability concepts (Garbie 2015a) within society at large, and of the potential rewards/benefits at the governmental level; a lack of consensus at the top level, a lack of awareness amongst members of localities of sustainability programs; negative attitudes towards the concept of sustainability; lack of support from employees; a lack of funds for green projects to offset the costs of unsustainable economic conditions, and difficulties in operation and maintenance (Garbie 2015b).

Although the concept and practices of SD were developed over the last 30 years, assessment of its index at different levels (starting from aspect/issue and dimension/pillar) still needs more attention from academics and manufacturers. Assessing sustainability practices is the main challenge faced by SMEs. This assessment also can be used to test manufacturing enterprises for sustainability and their potential to compete economically in the future. This paper will help SMEs' stakeholders to measure each aspect and dimension of SD, and identify the weakness of each one. Stakeholders in the SMEs will suggest solutions for the existing weakness. The main goals of this paper are:

- Understanding sustainability's concepts in SMEs,

- Understanding the most significant aspects and dimensions of sustainability,

- Considering the need for SMEs to become more sustainable and globalized, and

- New evaluations of SMEs in terms of SD.

To achieve this, a case study will be analyzed and evaluated for sustainability through the three dimensions/pillars of SD based on a combined approach published by Garbie $(2013,2014)$ and Winroth et al. (2012). This paper is organized into several sections. Section 2 discusses the literature 
regarding sustainability concepts, practices, and assessment. The proposed sustainability analysis will be presented in section 3. Sustainability assessments will be introduced in section 4 . Section 5 explains the implementation of the proposed analysis and measurements of sustainability in a real-life case study. Conclusions and recommendations for further work will be discussed in Section 6.

\section{Literature Review}

Many examples exist in the literature of SD as it applies to SMEs based on the number of employees in the company (lower than 500) according to Theyel and Hofmann (2012). Sustainability definitions and better communication in the process toward SD were presented by Glavic and Likman (2007). Sustainable engineering was recommended as a new educational course in engineering schools by Davidson et al. (2010). Hasna (2010) analyzed sustainability information in print press journals, periodicals and textbooks in order to provide a guideline for understanding sustainability science. Garetti and Taisch (2012) developed a fully detailed discussion about sustainable manufacturing which showed it to be one of the most pressing issues regarding SD. Liu et al. (2011) reviewed recent advances in the decision making process for supporting sustainable manufacturing operations through design, manufacturing, and supply chain management.

Bi (2011) broadly discussed manufacturing system requirements, both clarifying their limitations and discussing their potential bottlenecks. Rosen and Kishawy (2012) investigated the integration of sustainability with the lines of different objectives, including function, competitiveness, profitability and productivity, while Rosen (2012) identified key requirements for engineering sustainability, including resources, processes, increased efficiency, and reduced environmental impact. Lozano (2012) provided an analysis of the most widely known initiatives which aimed to embed sustainability into companies' systems. Theyel and Hofmann (2012) studied stakeholders' effects on companies' adoption of sustainability for social and environmental purposes by interacting with product and process innovation.

The importance of operational skills regarding business sustainability was conducted empirically in the SMEs of South Africa through five operations skills: inventory and operations management, quality control, productivity techniques, and support systems (Urban and Naidoo 2012). They indicated that entrepreneurs lack managerial skills. Lee (2009) explored and investigated the process of green management in SMEs for both the short-term (internal) and long-term views (external). He found that SMEs can make themselves greener by making strategic and organizational changes.

Martins et al. (2011) used group reporting initiative (GRI) to evaluate the efficiency of sustainability performance in a group of Brazilian manufacturing companies. Raising companies' awareness was suggested by using sustainability indicators as a new methodology by Veleva et al. (2001) and Veleva and Ellenbecker (2001). Ron (1998) suggested a five-step assessment procedure for sustainability. A framework for sustainable assessment was presented through the three dimensions of sustainability (Garbie 2013, 2014). The performance of sustainable production indicators by using fuzzy measure and the analytical network process (ANP) was evaluated (Tseng et al. 2009). A methodology for designing manufacturing metrics was developed, taking into consideration two specific concerns: the availability factor and time remaining (Weiser et al. 2008). A framework to assess the sustainability of operations in the manufacturing sector (Labuschagne et al. 2005) and for social assessment (Labuschagne and Brent 2008) was proposed. Leszczynska (2012) adopted the GRI standard and methodology as a point of reference to analyze the reports of sustainability published by multinational organizations. Performance assessment was developed by using a tool which considered a framework for sustainability indicators (Azapagic 2004). Integrating between sustainability pillars was investigated and studied to show which is more significant than the other (Garbie 2015c).

\section{Sustainability Analysis}

Analysis of sustainability in manufacturing enterprises is based on the dimensions of the triple bottom line (TBL): economy, society, and environment. Each dimension/pillar consists of several aspects/issues and each aspect/issue is based on several indicators. Each indicator is assessed by using performance metrics.

\subsection{Economic Analysis}

The essentials of economic sustainability considered in this section are business operations, employees, customer, research and development, operations management, and suppliers.

\subsubsection{Business Operations (A1)}

It is important to improve the business 
operations and financial returns of SMEs. As appropriate and timely business operations are made, sales and profit are considered major drivers/motivations to run a business, and the SMEs must focus on developing this issue.

\subsubsection{Employees (A2)}

Employees must be motivated and their productivity must be monitored. Employees' feelings concerning job security, motivation and workplace comfort, and the accessibility of employees' skills are considered indicators of employee satisfaction.

\subsubsection{Customers (A3)}

Customers are the ultimate target for SMEs and determine company success as they provide sales and profit. Ignoring customer satisfaction will lead to lost customer loyalty and a subsequent reduction in company revenue. Therefore, the rates of customer complaints and the addition of new customers per year are considered indicators for a SMEs's sustainability index (SDI).

\subsubsection{Research and Development (A4)}

Research and development (R\&D) and innovation can increase creativity and services offered by a company. R\&D also can help SMEs compete and remain sustainable at the market level. There are two indicators for measuring SI regarding R\&D: the number of new products related to the total number of existing products and the percentage of a company's annual budget that is devoted to R\&D.

\subsubsection{Operations Management (A5)}

Operation and production management includes activities related to manufacturing management. These activities are overall equipment efficiency, productivity, the performance rate of manual labor, the utilization of manual labor, delivery precision, manufacturing lead time, operation and production flexibility (eg. manufacturing flexibility), and a maintenance plan. These activities are also considered and used as indicators for the operation and production management SI.

\subsubsection{Suppliers (A6)}

Suppliers play an important role in the process of any SMEs as they offer raw materials, semifinished products, and equipment. Thus, the delivery precision of suppliers is very highly appreciated. Pauses in production due to suppliers' failings are used as indicators for measuring SI as it relates to suppliers.

\subsection{Social Analysis}

The second pillar of the TBL is the social dimension. There are five aspects represented by this pillar: employees' health, employees' knowledge, labor management relationships, diversity, and human capital. Each aspect has its own indicators.

\subsubsection{Employees' Health (B1)}

Health care services for employees within a workplace are extremely important. The investment in health benefits for employees must cover all SMEs because it is considered the major component of a sustainable industry. The number of accidents, employee absences due to on-the-job injury, and the rate of elimination of work place hazards are considered indicators for assessing sustainability regarding health and safety aspects.

\subsubsection{Employees' Knowledge (B2)}

Employees' knowledge depends on employees' levels of education, number of training hours received annually, and participation ratio in improvement activities. These are considered indicators of employees' knowledge.

\subsubsection{Labor Management Relationship (B3)}

The analysis of the labor-management relationship in the SMEs involves the investigation of rules and policies which govern and organize employment. These rules and policies are measured through two main indicators: the rate of temporary workers and number of employees who are shareholders.

\subsubsection{Diversity (B4)}

Understanding equity/equality means understanding the diversity between the social and cultural contributions of individuals. Therefore, providing different and/or flexible services for all employees is important: equal access and opportunity for individuals and groups who have specific needs should be met. The presence of diversity and equal opportunity, maleto-female ratio, cross-functional teams for improvements, and the prevalence of discrimination are used as indicators to assess the SI for diversity and equal opportunity.

\subsubsection{Human Capital (B5)}

The human capital aspect represents the value of SMEs in a community. SMEs are found in specific regions and lead to job generation. They focus on the capacities of groups of people and their interactions. In this paper, some indicators are modified to assess the sustainability of human 
capital. These indicators are company wages as they relate to the local minimum wage, the number of new employees hired per year, employee satisfaction rate, support for employees' physical activities, health care and medical benefits offered, turnover rate, responsibility and competence, the clarity of employees' job descriptions and promotion opportunities for all employees.

\subsection{Environmental Analysis}

The environment can be affected and damaged by manufacturing-related causes. These causes include instability/inefficiency of equipment and a high rate of natural resource consumption. In order to attain environmental sustainability, SMEs may require a set of changes in these issues which are represented by manufacturing/industrial processes, type of equipment, amount of natural resources consumed, and waste management. Therefore, SMEs may face many challenges to adapting and implementing changes. The five aspects/issues for environmental sustainability analysis will be discussed below.

\subsubsection{Natural Resources (C1)}

Natural resources are defined as land use, water consumption, the use of recycled water, purification of waste water, and rate of resource reuse. The availability of these resources plays an important role for SMEs. There are many SMEs which are considered high water consumers including refineries, petrochemical plants, special chemical producers, pulp and paper industries, electric equipment, and the food industry. Some SMEs have reduced water consumption by reusing wastewater, regenerating water supplies, and implementing recycling or process changes.

\subsubsection{Energy (C2)}

The manufacturing sector in SMEs is a major consumer of energy which results in greenhouse gas emissions. In order to achieve energy efficiency and protect the environment, emissions of greenhouse gases and their resultant air pollution as well as fossil fuel consumption can be reduced, and the percentage of renewable energy use can be increased. In addition, it also measures renewable energy used by manufacturers. Sometimes it is difficult to use renewable energy for the main area of production due to heavy power consumption, but it easily can be applied to lighting and/or air conditioning use. Three indicators are used to determine the SI of energy: the use of renewable energy sources, net energy use, and idle energy losses.

\subsubsection{Materials (C3)}

Raw materials mainly are extracted from the Earth, meaning supplies will be limited. Therefore, the used material can be reduced by adopting new technologies such as recycling and remanufacturing. The recycling/reassembly of materials can extend their useful life beyond discarding them. There are four indicators used to assess SI in relation to raw materials: net material usage, scrape rate, the rate of packing material, and the use of process additives.

\subsubsection{Waste and Emissions (C4)}

Waste and emissions are identified inefficiencies in the production process. Environmental protection incorporates new techniques and processes for the treatment and disposal of waste. SMEs can achieve environmental sustainability by waste and disposal elimination, thereby improving efficiency. In this paper, six indicators are suggested to assess SI regarding waste and emissions: total solid waste, weight of hazardous waste, emission of ozone-depleting substances, emissions causing acid rain, and the emission of particles of carbon dioxide.

\subsubsection{Environmental Management (C5)}

The SI of environmental legality and standard compliance is assessed by using four indicators. These indicators are represented as environmental accidents, cost for environmental health and safety, ISO 14001 compliance, and environmental management systems.

\section{Sustainability Assessments}

Sustainability assessments are measured through the definition of proposed aspects and indicators. Sustainable indicators have specific characteristics which come into consideration when designing a framework for assessing sustainability: measurable (quantitatively and/or qualitatively), relevant, understandable, and reliable (Garbie 2013, 2014; Rosen and Kishawy 2012). A procedure to assess the dimensions of sustainability is introduced and used in assessing the strengths and weaknesses of the SMEs. The triple bottom line (TBL) is used to identify the intersection between pillars of sustainability (Fig. $1)$, suggesting that the intersection between sustainability pillars is not strong enough and needs more explanation to ensure the meaning of this value. Figure 2 illustrates the strong relationship between sustainability pillars not only in interactions but also in incorporation. This means that economic sustainability is the core 


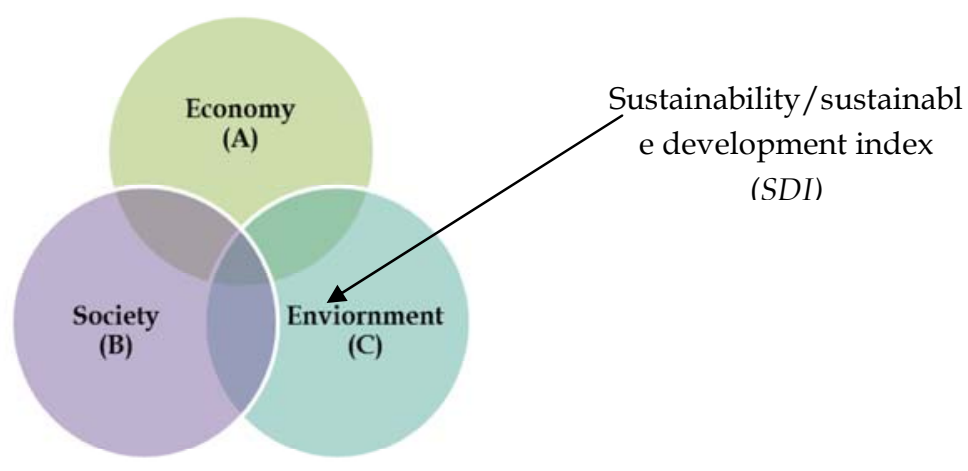

Figure 1. Interacting between the triple bottom line (TBL) of sustainability pillars.

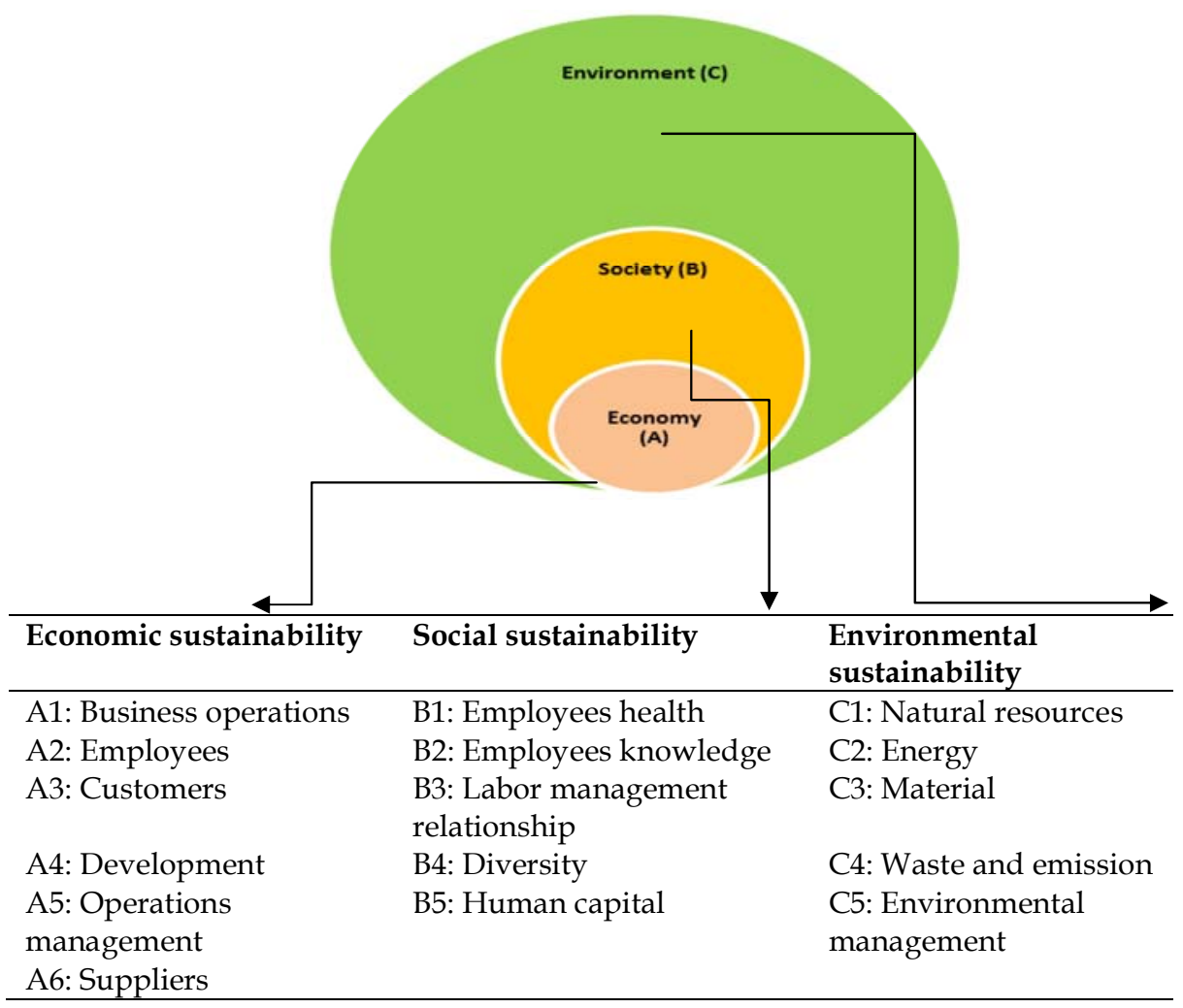

Figure 2. Incorporating between sustainability pillars.

$$
\begin{aligned}
& A 1 \quad A 2 \quad A 3 \quad A 4 \quad A 5 \quad A 6 \\
& A 1\left[\begin{array}{cccccc}
1 & \frac{w_{A 1}}{w_{A 2}} & \frac{w_{A 1}}{w_{A 3}} & \frac{w_{A 1}}{w_{A 4}} & \frac{w_{A 1}}{w_{A 5}} & \frac{w_{A 1}}{w_{A 6}}
\end{array}\right] \\
& A 2 \mid \begin{array}{llllll}
\frac{w_{A 2}}{w_{A 1}} & 1 & \frac{w_{A 2}}{w_{A 3}} & \frac{w_{A 2}}{w_{A 4}} & \frac{w_{A 2}}{w_{A 5}} & \frac{w_{A 2}}{w_{A 6}}
\end{array} \\
& A=\begin{array}{c|cccccc}
A 3 & \frac{w_{A 3}}{w_{A 1}} & \frac{w_{A 3}}{w_{A 2}} & 1 & \frac{w_{A 3}}{w_{A 4}} & \frac{w_{A 3}}{w_{A 5}} & \frac{w_{A 3}}{w_{A 6}} \\
A 4 & \frac{w_{A 4}}{w_{A 1}} & \frac{w_{A 4}}{w_{A 2}} & \frac{w_{A 4}}{w_{A 3}} & 1 & \frac{w_{A 4}}{w_{A 5}} & \frac{w_{A 4}}{w_{A 6}}
\end{array} \\
& A 5 \mid \begin{array}{llllll}
\frac{w_{A 5}}{w_{A 1}} & \frac{w_{A 5}}{w_{A 2}} & \frac{w_{A 5}}{w_{A 3}} & \frac{w_{A 5}}{w_{A 4}} & 1 & \frac{w_{A 5}}{w_{A 6}}
\end{array} \\
& A 6\left[\begin{array}{llllll}
\frac{w_{A 6}}{w_{A 1}} & \frac{w_{A 6}}{w_{A 2}} & \frac{w_{A 6}}{w_{A 3}} & \frac{w_{A 6}}{w_{A 4}} & \frac{w_{A 6}}{w_{A 5}} & 1
\end{array}\right]
\end{aligned}
$$


aspect of sustainability, followed by society and environment.

\subsection{Framework Design}

The main objective of designing a framework is to present a procedure for SMEs to assess their sustainability levels. The issues/aspects of each pillar were chosen and filtered after looking through different references throughout this framework based on the proposed mathematical framework published by Garbie $(2013,2014)$ and an analysis proposed by Winroth et al. (2012). Indicators were assigned based on an appropriate unit of measurement. The unit for each indicator was selected to be either quantitative or qualitative. The proposed framework is based on determining the existing performance and the target value for each indictor. This procedure assists SMEs in understanding the difficulties within an existing status. This procedure can be also used to increase companies' awareness of sustainability.

The framework suggests a matrix that reflects the relative weights representing the relationship between all aspects in each pillar. These relationships also indicate the importance of each aspect relative to other aspects as shown in the following matrices. The relative weight of each aspect is measured using an analytical hierarchy process (AHP) (Garbie et al. 2008a and b; Garbie 2012; Garbie and Shikdar 2011a and b). The relative weights using AHP are estimated and changed frequently according to the new circumstance determined by a decision maker or a group of decision makers (Garbie 2013) as shown in Eqns. (1-3). These groups are represented by senior management, manufacturing and/or production management, and plant managers. The proposed framework of each dimension is shown in Tables 13 individually.

Table 1. Economic sustainability framework.

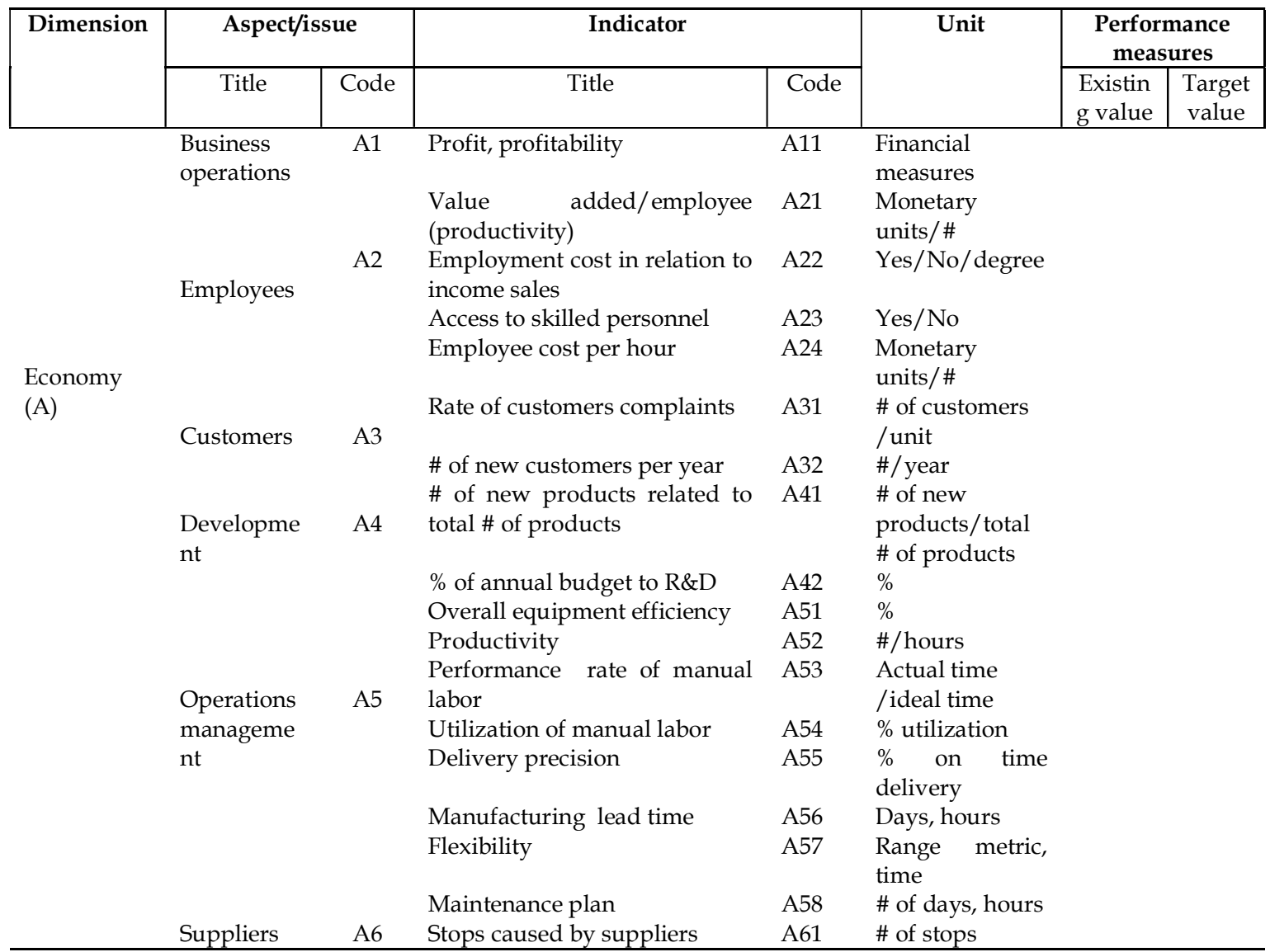


Table 2. Social sustainability framework.

\begin{tabular}{|c|c|c|c|c|c|c|c|}
\hline \multirow[t]{2}{*}{$\begin{array}{l}\text { Dime } \\
\text { nsion }\end{array}$} & \multicolumn{2}{|c|}{ Aspect/issue } & \multicolumn{2}{|l|}{ Indicator } & \multirow[t]{2}{*}{ Unit } & \multicolumn{2}{|c|}{$\begin{array}{c}\text { Performance } \\
\text { measures }\end{array}$} \\
\hline & Title & Code & Title & Code & & $\begin{array}{l}\text { Existing } \\
\text { value }\end{array}$ & $\begin{array}{l}\text { Target } \\
\text { value }\end{array}$ \\
\hline \multirow{20}{*}{$\begin{array}{l}\text { Social } \\
\text { (B) }\end{array}$} & Employees & & $\#$ of accidents & B11 & \# & & \\
\hline & Health & B1 & $\begin{array}{l}\text { Absence due to injuries or } \\
\text { relate illness }\end{array}$ & B12 & \# of days & & \\
\hline & & & $\begin{array}{l}\text { Elimination of hazard work } \\
\text { places }\end{array}$ & B13 & $\begin{array}{l}\text { Yes/No/De } \\
\text { gree }\end{array}$ & & \\
\hline & & & \# of training hours/employee & B21 & \# of hours & & \\
\hline & $\begin{array}{l}\text { Employees } \\
\text { knowledge }\end{array}$ & B2 & $\begin{array}{l}\text { Participation ratio in } \\
\text { improvement group }\end{array}$ & B22 & $\begin{array}{l}\# \quad \text { of } \\
\text { group/\# of } \\
\text { employees }\end{array}$ & & \\
\hline & & & Level of education & B23 & $\begin{array}{l}\text { Average } \\
\text { Level }\end{array}$ & & \\
\hline & $\begin{array}{l}\text { Labor- } \\
\text { management } \\
\text { relationship }\end{array}$ & B3 & Rate of temporary workers & B31 & $\begin{array}{l}\# \text { of } \\
\text { temporary/ } \\
\# \text { of } \\
\text { permanent }\end{array}$ & & \\
\hline & & & $\begin{array}{l}\text { Rate of employees that are } \\
\text { share holders }\end{array}$ & B32 & $\%$ & & \\
\hline & Diversity & B4 & Equal opportunity & B41 & $\begin{array}{l}\text { Yes/No/De } \\
\text { gree }\end{array}$ & & \\
\hline & & & Male to female ratios & B42 & $\begin{array}{l}\# \text { of } \\
\text { female/\# of } \\
\text { employees }\end{array}$ & & \\
\hline & & & Cross functional teams & B43 & \# of teams & & \\
\hline & & & Discrimination & B44 & $\begin{array}{l}\text { Yes/No/De } \\
\text { gree }\end{array}$ & & \\
\hline & & & $\begin{array}{l}\text { Company wage relate to local } \\
\text { minimum wage }\end{array}$ & B51 & $\%$ & & \\
\hline & & & \# of new employees per year & B52 & \# & & \\
\hline & & & Employee satisfaction rate & B53 & $\%$ & & \\
\hline & $\begin{array}{l}\text { Human } \\
\text { capital }\end{array}$ & B5 & $\begin{array}{l}\text { Support for employee physical } \\
\text { activity, health care and } \\
\text { medicine }\end{array}$ & B54 & Yes/No & & \\
\hline & & & Employees turnover & B55 & $\begin{array}{l}\% \quad \text { annual } \\
\text { turnover } \\
\text { rate }\end{array}$ & & \\
\hline & & & Responsibility and competence & B56 & $\begin{array}{l}\text { Yes/No/De } \\
\text { gree }\end{array}$ & & \\
\hline & & & Clear job descriptions & B57 & $\begin{array}{l}\text { Yes/No/De } \\
\text { gree }\end{array}$ & & \\
\hline & & & Promotion opportunities & B58 & $\begin{array}{l}\text { Yes/No/De } \\
\text { gree }\end{array}$ & & \\
\hline
\end{tabular}


Table 3. Environment sustainability framework.

\begin{tabular}{|c|c|c|c|c|c|c|c|}
\hline \multirow[t]{2}{*}{ Dimension } & \multicolumn{2}{|c|}{ Aspect/issue } & \multicolumn{2}{|l|}{ Indicator } & \multirow[t]{2}{*}{ Unit } & \multicolumn{2}{|c|}{$\begin{array}{c}\text { Performance } \\
\text { measures }\end{array}$} \\
\hline & Title & Code & Title & Code & & $\begin{array}{l}\text { Existin } \\
\mathrm{g} \\
\text { value }\end{array}$ & $\begin{array}{c}\text { Targ } \\
\text { et } \\
\text { value }\end{array}$ \\
\hline \multirow{23}{*}{$\begin{array}{l}\text { Environment } \\
\text { (C) }\end{array}$} & \multirow{5}{*}{$\begin{array}{l}\text { Natural } \\
\text { resources }\end{array}$} & \multirow{5}{*}{$\mathrm{C} 1$} & Land consumption & C11 & \multicolumn{3}{|l|}{ Square meter } \\
\hline & & & Water consumption & C12 & Cubic meter & & \\
\hline & & & Recycled water & C13 & $\begin{array}{l}\% \quad \text { of } \\
\text { consumption }\end{array}$ & & \\
\hline & & & $\begin{array}{l}\text { Purification of waste } \\
\text { water }\end{array}$ & $\mathrm{C} 14$ & 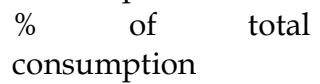 & & \\
\hline & & & $\begin{array}{l}\text { Share of reuse or } \\
\text { recycled }\end{array}$ & C15 & $\begin{array}{lcl}\% & \text { of } & \text { total } \\
\text { consumption } & \end{array}$ & & \\
\hline & \multirow[t]{5}{*}{ Energy } & \multirow[t]{5}{*}{$\mathrm{C} 2$} & $\begin{array}{l}\text { Use of renewable } \\
\text { energy }\end{array}$ & $\mathrm{C} 21$ & $\%$ of total energy & & \\
\hline & & & Energy use & $\mathrm{C} 22$ & kWh energy use per & & \\
\hline & & & & & & & \\
\hline & & & Idle of energy losses & C23 & $\begin{array}{l}\mathrm{kWh} \text { idle time } \\
\text { energy use }\end{array}$ & & \\
\hline & & & Material usage & C31 & $\begin{array}{l}\mathrm{kg} \text { or cubic meter per } \\
\text { unit }\end{array}$ & & \\
\hline & \multirow[t]{5}{*}{ Material } & \multirow[t]{5}{*}{$\mathrm{C} 3$} & Scrap rate & $\mathrm{C} 32$ & $\%$ of material usage & & \\
\hline & & & $\begin{array}{l}\text { Rate of packing } \\
\text { material }\end{array}$ & C33 & $\%$ of material usage & & \\
\hline & & & $\begin{array}{l}\text { Use of process } \\
\text { additive }\end{array}$ & C 34 & $\%$ of material usage & & \\
\hline & & & Total solid waste & C41 & $\begin{array}{l}\mathrm{kg} \text { or cubic solid } \\
\text { waste }\end{array}$ & & \\
\hline & & & $\begin{array}{l}\text { Weight of hazardous } \\
\text { waste }\end{array}$ & $\mathrm{C} 42$ & $\begin{array}{l}\mathrm{kg} \text { or cubic meter of } \\
\text { hazardous waste }\end{array}$ & & \\
\hline & \multirow[t]{4}{*}{$\begin{array}{l}\text { Waste } \\
\text { and } \\
\text { Emission }\end{array}$} & \multirow[t]{4}{*}{$\mathrm{C} 4$} & $\begin{array}{l}\text { Emission of ozone- } \\
\text { depleting substances }\end{array}$ & $\mathrm{C} 43$ & $\begin{array}{l}\mathrm{kg} \text { or cubic meter } \\
\text { ozone-depleting } \\
\text { substances }\end{array}$ & & \\
\hline & & & $\begin{array}{l}\text { Emission causing } \\
\text { acid rain }\end{array}$ & C44 & $\begin{array}{l}\mathrm{kg} \text { or cubic meter of } \\
\text { emission of NOx }\end{array}$ & & \\
\hline & & & Emission of particles & C45 & $\begin{array}{l}\mathrm{kg} \text { emission of } \\
\text { particles }\end{array}$ & & \\
\hline & & & $\begin{array}{l}\text { Emission of carbon } \\
\text { dioxide }\end{array}$ & $\mathrm{C} 46$ & $\begin{array}{l}\mathrm{kg} \text { emission } \\
\text { carbon dioxide }\end{array}$ & & \\
\hline & \multirow{4}{*}{$\begin{array}{l}\text { Environ } \\
\text { mental } \\
\text { manage } \\
\text { ment }\end{array}$} & \multirow[t]{4}{*}{ C5 } & $\begin{array}{l}\text { Environmental } \\
\text { accidents }\end{array}$ & C51 & \# of accidents & & \\
\hline & & & $\begin{array}{l}\text { Cost of EHS } \\
\text { compliance }\end{array}$ & C52 & Monetary units & & \\
\hline & & & $\begin{array}{l}\text { Compliance with ISO } \\
14001\end{array}$ & C53 & Yes/No & & \\
\hline & & & $\begin{array}{l}\text { Environmental } \\
\text { impact assessment is } \\
\text { used }\end{array}$ & C54 & Yes/No & & \\
\hline
\end{tabular}




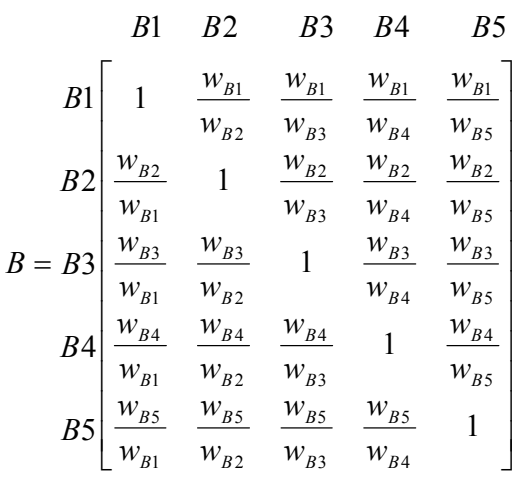

\subsection{Mathematical Approach for Assessing Sustainability}

The mathematical model for measuring the SDI was developed by Garbie $(2013,2014)$ and is used to assess the proposed framework, especially in the Eqns. 4 and 6. It contains a set of equations that can be used to calculate the SDI of each dimension/pillar through the calculation of each aspect/issue as follows:

$$
S D I_{j}=\prod_{m=1}^{m_{j}}\left(\frac{T_{m_{j}}}{E_{m_{j}}}\right)^{Y_{m_{j}}}
$$

Where: $S D I_{j}=$ sustainable development index for aspect/issue $j, Y_{m j}=$ exponent of the change towards sustainability for indicator $m$ in each aspect $j, T_{m j}=$ value of indicator $m$ towards sustainability, $E_{m j}=$ value of indicator $m$ regarding the existing status, and $m_{j}=$ number of indicators of aspect/issue $j$.

$$
Y_{m_{j}}=\log \left|T_{m_{j}}-E_{m_{j}}\right|
$$

The SDI for each dimension/pillar is estimated by using Eqn. 6 .

$$
S D I_{i}=\sum_{j=1}^{n_{i}} w_{j} S D I_{j}
$$

Where: $S D I_{i}=$ sustainable development index for dimension/pillar $i$ (economic sustainability, social sustainability, environmental sustainability), relative weight for each aspect $j, n_{j}=$ number of aspects in the dimension $i . w_{j}=$ relative weights between aspects/issues for each pillar and they are

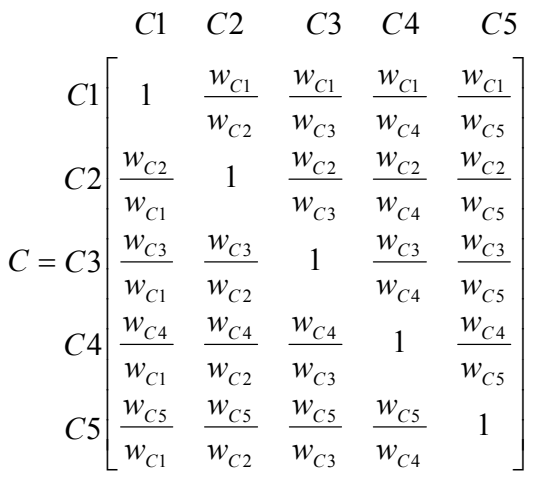

determined as references (Garbie et al. 2008a and b; Garbie 2012 and 2015d; Garbie and Shikdar 2011a and $b)$. The general SDI is estimated as Eqn. 7 .

$S D I=\sum_{i=1}^{3} w_{i} S D I_{i}=w_{A} S D I_{A}+w_{B} S D I_{B}+w_{C} S D I_{C}$

Where, SDI is based on three pillars of sustainability (economic, social, and environmental) and the $w_{i}=$ the relative weight associated with sustainable development for each dimension/pillar $i$.

\section{Case Study and Implementation}

\section{Business Operations (A1)}

Table 4 shows that the ABC Company's output is about $96.6 \%$ through the use of Eqn. 4 . As a result, the ABC Company needs $96.6 \%$ more effort (time and cost) than the existing value regarding business operations aspects.

\section{Employees (A2)}

The SDI for employees is $129.18 \%$. This value means that, in this respect, the $\mathrm{ABC}$ Company needs $129.18 \%$ more effort than the existing value. With respect to upgrading the SDI in this aspect, the $\mathrm{ABC}$ Company would have to increase the rate of employees' pay. The ABC Company had to search extensively for highly skilled workers, showing that their pay rates were too low. It would be important to increase pay to gain more loyalty from employees.

\section{Customers (A3)}

In this respect, the $\mathrm{ABC}$ Company has to increase the effort by 1.54 times (SDI $=154.80 \%$ ) over the existing value. It was mentioned that the number of customers per year was two while the willing number was forecast to reach up to five. 
Table 4. Sustainability indexes for aspects and economic dimensions.

\begin{tabular}{|c|ccc|c|c|}
\hline $\begin{array}{c}\text { Indicators } \\
\text { code }\end{array}$ & \multicolumn{2}{|c|}{$\begin{array}{c}\text { Performance measures } \\
\text { Existing }\end{array}$} & $\begin{array}{c}\text { Aspect/ } \\
\text { Target }\end{array}$ & $\begin{array}{c}\text { Economic } \\
\text { index }\end{array}$ & $\begin{array}{c}\text { sustainability } \\
\text { index }\end{array}$ \\
\hline A11 & 3.37 & 4 & 0.966 & \\
A21 & 70 & 90 & & \\
A22 & YES & YES & 1.291 & \\
A23 & YES & YES & & \\
A23 & 2 & 2.25 & & \\
A31 & 0.1 & 0 & 1.548 & \\
A32 & 2 & 5 & & \\
A41 & 10 & 20 & 2.213 & \\
A42 & 5 & 7 & & \\
A51 & 80 & 87 & & \\
A52 & 10 & 15 & & \\
A53 & 86 & 93 & & \\
A54 & 75 & 81 & 2.792 & \\
A55 & 90 & 100 & & \\
A56 & 2 & 1.6 & & \\
A57 & 60 & 80 & & \\
A58 & 1 & 0.8 & & \\
A61 & NO & NO & 0.0 & \\
\hline
\end{tabular}

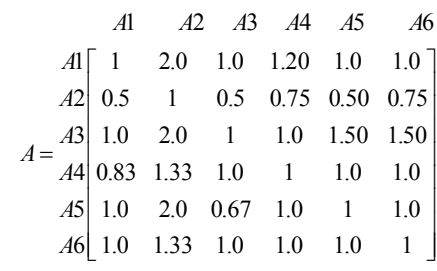

Therefore, the company would have to expend much more effort in this respect based on marketing and advertising.

\section{Development (A4)}

In regard to money spent to produce a new product or improving the existing one, it can be noted that the results is $213.30 \%$. This means more effort towards sustainability is required than the existing one (Table 4).

\section{Operations Management (A5)}

Operations management includes the activities in the plant and was identified by several indicators. The SDI of production management was $279.20 \%$, and the ABC Company has to work hard in this respect. The $\mathrm{ABC}$ Company requires almost three-and-a-half times more effort beyond what they make currently. In this respect, the $A B C$
Company struggles because of late delivery and customer complaints. It can be noted that productivity and efficiency is an area of high consideration for employees and machines, respectively.

\section{Suppliers (A6)}

The SDI of the suppliers is almost zero, and the $\mathrm{ABC}$ Company does not need any more effort for this aspect as it has several suppliers of aluminum.

The relative economic weights of the aspects appear in the matrix represented by Eqn. (8) and were estimated by using AHP with computing consistency and random indexes as 0.1884, 0.1056, $0.1967,0.166,0.1720$ and 0.1713 for business operations, including employees, customers, development, operation management, and suppliers, respectively (Table 4). The results are acceptable based on the inconsistency ratio which is less than 0.10. Finally, after using Eqn. 6, the economic sustainability index will be calculated as $1.470(0.966 * 0.1884+1.2918 * 0.1056+1.548$ * $0.1967+2.213 * 0.166+2.792 * 0.172+0=1.470)$. This value means that the ABC Company needs to exert 1.47 times (147\%) more effort towards economic sustainability. 
Table 5. Sustainability indexes for aspects and social dimension.

\begin{tabular}{|c|cc|c|c|}
\hline \multirow{2}{*}{$\begin{array}{c}\text { Indicators } \\
\text { code }\end{array}$} & \multicolumn{2}{|c|}{$\begin{array}{c}\text { Performance } \\
\text { Measures }\end{array}$} & $\begin{array}{c}\text { Aspect/ } \\
\text { issue } \\
\text { index }\end{array}$ & $\begin{array}{c}\text { Social } \\
\text { sustainability } \\
\text { index }\end{array}$ \\
\cline { 2 - 3 } B11 & Existing & Target & & \\
B12 & 7 & $1 \sim 0$ & & \\
B13 & YES & $1 \sim 0$ & 0.048 & \\
B21 & 7 & YES & & \\
B22 & 5 & 7 & & \\
B23 & 2 & 3 & & \\
B31 & N/A & N/A & 2.635 & \\
B32 & $0-1$ & 5 & & \\
B41 & YES & YES & & \\
B42 & $10 / 350$ & $15 / 350$ & & \\
B43 & 5 & 7 & 1.4636 & \\
B44 & NO & NO & & \\
B51 & 80 & 90 & & \\
B52 & 10 & 12 & & \\
B53 & 80 & 95 & & \\
B54 & YES & YES & & \\
B55 & 20 & 10 & 0.73 & \\
B56 & YES & YES & & \\
B57 & YES & YES & \\
B58 & YES & YES & & \\
\hline
\end{tabular}

$$
\begin{aligned}
& \begin{array}{lllll}
B 1 & B 2 & B 3 & B 4 & B 5
\end{array} \\
& \begin{array}{r}
B 1 \\
B 2 \\
B 3 \\
B 4 \\
B 5
\end{array}\left[\begin{array}{ccccc}
1 & 1.0 & 2.0 & 2.0 & 1.0 \\
1.0 & 1 & 2.0 & 1.5 & 2.0 \\
0.5 & 0.5 & 1 & 0.2 & 0.5 \\
0.5 & 0.67 & 5.0 & 1 & 0.75 \\
1.0 & 0.50 & 2.0 & 1.33 & 1
\end{array}\right]
\end{aligned}
$$

\subsection{The Dimension of Social Sustainability}

In this analysis of the ABC Company, the collected data from five aspects were analyzed in areas of employee health, employee knowledge, labor-management relationships, diversity, and human capital (Table 5).

\section{Employees Health (B1)}

The output results show that the ABC Company puts about $4.8 \%$ of its effort toward sustainability as compared with the existing one in regards to safety and health. The ABC Company gives more attention to the dangerous material and hazard, spending approximately RO 20,000 US\$ 50,000 per year in safety and health. The ABC Company has an appropriate level of safety as well as instructors who do a good job helping employees avoid hazards. The company provides adequate safety equipment's.

\section{Employees' Knowledge (B2)}

The resulting value of social sustainability regarding employees' knowledge is about $119 \%$. The data show that the numbers of training hours, levels of education and participation ratios in the improvement group are high. It can be seen that the average level of education in the $A B C$ Company is low with others having achieved only a high school degree.

\section{Labor management Relationship (B3)}

The data show that the value of labor management relationship is about 2.635 times. The reasons behind this low value is that the $A B C$ Company has almost no shareholders among its employees and also because it has a small number of temporary workers. Labor management relationship aspect is a very important in achieving social sustainability; the ABC Company should make a greater effort in this area.

\section{Diversity (B4)}

The estimated value of diversity and equal opportunity needed to reach social sustainability is $146.80 \%$. In this aspect, more effort is needed in the number of cross functional teams in order to 
achieve improvements in the ABC Company. Also, the company needs to increase the number of females it employs. However, the ABC Company provides equal opportunities for all employees and does not discriminate based on gender, disability, or race.

\section{Human Capital (B5)}

The value of social sustainability regarding human capital in the ABC Company is $73 \%$. This value reflects the percentage of improvement that the company should achieve in order to reach social sustainability in human capital. The ABC Company has good human capital but it needs to exert more effort to accomplish higher employee satisfaction. It needs also to increase the number of new employees each year.

The relative weight of social sustainability based on the matrix represented by Eqn. 9 were estimated as 0.2423, 0.2638, 0.094, 0.2064, and 0.1930 for employee's health, employee's knowledge, labor management relationship, diversity, and human capital, respectively while the results is accepted based on the inconsistency ratio which is less than 0.10. Finally, and after using Eqn. (6), the social sustainability index will be calculated as 1.018 . The ABC Company has to achieve almost 1.018 times $(101.80 \%)$. This value means that the social aspects need double more effort especially in labor management relationship, employees' knowledge, and human capital.

\subsection{The Dimension of Environmental Sustainability}

According to the survey of the ABC Company (Table 6), the data were analyzed as follows:

\section{Natural Resources (C1)}

The results show that $148.66 \%$ of the effort is needed regarding natural resources towards sustainability as compared with the existing value. Also, since the ABC Company uses large amounts of water, recycling this resource will reduce consumption.

\section{Energy (C2)}

The estimated value of the energy sustainability aspect index is $17.50 \%$. The Company uses regular, fossil fuel-driven energy sources due to the manufacturing processes and does not have plans to change to renewable energy. Thus, because renewable sources cannot provide enough energy at a suitable cost, this concept was misunderstood by the managers of the company.

\section{Material (C3)}

The value of the environmental SDI regarding material is about $77.70 \%$. This means that the $A B C$ Company has to increase its effort towards sustainability by $77.70 \%$ over the existing value. The main raw material used is aluminum, which is imported from Dubai City. In addition, they import different kinds of paint based on customer orders. The ABC Company has a good recycling plan which involves sending the materials back to Dubai for recycling and reuse.

\section{Waste and Emission (C4)}

The resulting value of the environmental SDI regarding waste and emissions was about $131.20 \%$. The collected data show that the total emissions from solid waste and ozone depleting $\mathrm{CO}_{2}$ and $\mathrm{NO}_{3}$ are not high.

\section{Environmental Legal and Standard Compliance (C5)}

It can be observed that the value of the environmental SDI regarding environmental legal and standard compliance was $197.90 \%$. This area does not need more effort.

The relative weights of environmental sustainability were estimated based on the matrix represented by Eqn. 10 and using AHP: 0.2494, $0.1168,0.2494,0.20$, and 0.1834 for natural resources, energy, materials, waste and emissions, and environmental system management, respectively (see Table 6) while the results is accepted based on the inconsistency ratio which is less than 0.10. Finally, and after using Eqn. (6), the environmental sustainability index will be calculated as 1.21. This means that the $A B C$ Company needs to exert $121 \%$ more than their existing effort towards environmental sustainability when compared with the existing value.

\subsection{Overall Sustainability Index (SDI)}

The overall sustainability index for the $A B C$ Company equals $123 \%$ [ $(1.470+1.018+1.210) /$ 3=1.23)] based on Eqn. 7, with equal relative weights between the pillars/dimensions of sustainability. Table 7 is used to illustrate the percent of each pillar/dimension of sustainability index with respect to the whole value. 
Table 6. Sustainability indexes for aspects and environmental dimension.

\begin{tabular}{|c|c|c|c|c|}
\hline \multirow[t]{2}{*}{$\begin{array}{l}\text { Indicators } \\
\text { code }\end{array}$} & \multicolumn{2}{|c|}{$\begin{array}{l}\text { Performance } \\
\text { Measures }\end{array}$} & \multirow{2}{*}{$\begin{array}{l}\text { Aspect/ } \\
\text { issue } \\
\text { Index }\end{array}$} & \multirow{2}{*}{$\begin{array}{c}\text { Environmental } \\
\text { sustainability } \\
\text { index }\end{array}$} \\
\hline & Existing & Target & & \\
\hline C11 & 49000 & 55000 & & \\
\hline C12 & 3650 & 3500 & & \\
\hline C13 & 65 & 70 & 1.4866 & \\
\hline C14 & 0 & 0 & & \\
\hline C15 & 1 & 2 & & \\
\hline C21 & $\mathrm{N} / \mathrm{A}$ & $\mathrm{N} / \mathrm{A}$ & & \\
\hline C22 & 1260950 & 1386825 & 0.175 & \\
\hline C23 & 600 & 250 & & \\
\hline C31 & 1500 & 1700 & & \\
\hline C32 & 35 & 20 & 0.777 & \\
\hline C33 & 80 & 90 & & 1.21 \\
\hline C 34 & 2 & 3 & & \\
\hline C41 & 1000 & 850 & & \\
\hline $\mathrm{C} 42$ & 50 & 20 & & \\
\hline C43 & 0.05 & 0.01 & 1.312 & \\
\hline C44 & $\mathrm{N} / \mathrm{A}$ & $\mathrm{N} / \mathrm{A}$ & & \\
\hline C45 & 3 & 1 & & \\
\hline $\mathrm{C} 46$ & 5 & 4 & & \\
\hline C51 & 7 & 0 & & \\
\hline C52 & 30000 & 50000 & & \\
\hline C53 & $\mathrm{NO}$ & $\mathrm{NO}$ & 1.979 & \\
\hline C54 & $\mathrm{NO}$ & $\mathrm{NO}$ & & \\
\hline
\end{tabular}

Table 7. Percentage of pillar/dimension sustainability.

\begin{tabular}{lcc}
\hline Pillar/Dimension & Value & \% \\
\hline Economy (A) & 1.470 & 40.00 \\
Society (B) & 1.018 & 27.50 \\
Environment (C) & 1.210 & 32.50 \\
\hline
\end{tabular}

$$
\left.\begin{array}{rccccc}
C 1 & C 1 & C 2 & C 3 & C 4 & C 5 \\
C 2 & 1 & 2.0 & 1.0 & 2.0 & 1.0 \\
C .5 & 1 & 0.50 & 0.50 & 0.75 \\
C 4 & 1.0 & 1.0 & 1 & 2.0 & 1.0 \\
C 5 & 0.67 & 0.50 & 0.50 & 1 & 2.0 \\
1.0 & 0.50 & 1.0 & 0.5 & 1
\end{array}\right]
$$

Determination the importance of flexible weights between dimensions of sustainability pillars in general/overall sustainability index is shown in Table 8 based on the different perspectives of the stakeholders. This flexibility is representing the sensitivity analysis of the relative weights between sustainability pillars/dimensions. Table 8 is used to illustrate the differences between the relative weights between sustainability pillars and the overall sustainability index (SDI). It can be noticed from Table 8 that when the importance of economic dimension increase $(25-40 \%)$, the overall sustainability index is also increased (from 1.198 to 1.267). This means that economic value is important and significant in sustainable development and it can be achieved within its requirements. The associated changing of social pillar was decreased from $40.0 \%$ to $25.0 \%$. This is no significant changes and significant in sustainable development and it can be achieved within its requirements. The associated changing of social pillar was decreased from $40.0 \%$ to $25.0 \%$. This is no significant changes in social pillar comparing with economic and/or environmental dimension which keeps constant values. 
Table 8. Comparing between different perspectives.

\begin{tabular}{cccccccc}
\hline Perspective \# & $w_{A}$ & $w_{B}$ & $w_{C}$ & $I_{A}$ & $I_{B}$ & $I_{C}$ & $S I$ \\
\hline 1 & 0.25 & 0.40 & 0.35 & 1.470 & 1.018 & 1.210 & 1.198 \\
2 & 0.30 & 0.35 & 0.35 & 1.470 & 1.018 & 1.210 & 1.220 \\
3 & 0.33 & 0.33 & 0.33 & 1.470 & 1.018 & 1.210 & 1.230 \\
4 & 0.35 & 0.30 & 0.35 & 1.470 & 1.018 & 1.210 & 1.243 \\
5 & 0.40 & 0.25 & 0.35 & 1.470 & 1.018 & 1.210 & 1.267 \\
\hline
\end{tabular}

\section{Conclusion, Contribution and Recommendations for Future Work}

In this paper, an approach for assessing sustainability in SMEs was analyzed and investigated through a case study applied to different dimensions of sustainability (economy, society and environment). The case study shows that economic sustainability represents the highest value of sustainable development $(40 \%)$ followed by environmental sustainability $(32.50 \%)$ and social sustainability $(27.50 \%)$ based on equal relative weights between sustainability pillars. This means more effort is needed to achieve economic sustainability than social and environmental sustainability. For the economic dimension, more work is still needed, especially in operations and production management; customers' issues and development expenditures. With respect to environmental sustainability, some efforts are required in the areas of environmental, legal, and standard compliance. These results might change when applying the proposed approach in different studies. This means that SDI in any manufacturing enterprise, and especially SMEs, requires both human and institutional capacities in innovation, development, assessment, adaptation and diffusion. These capacities are considered requirements for supporting an industrial organization's mission.

The main contribution of this paper is to analyze and investigate the sustainability/sustainable development index in manufacturing enterprises through the real case study. This paper also illustrates how it is possible to model and assess sustainability indicators, and the proposed approach has become very useful assessment tool. The author is looking to apply the proposed approach with its associated questionnaires among numerous industrial companies to identify the index of sustainability/sustainable development index and to show the most common and the feasibility of sustainability indicators and performance measures.

\section{References}

Azapagic A (2004), Developing a framework for sustainable development indictors for the mining and minerals industry. Journal of Cleaner Production 12: 639-662.

Bi Z (2011), Revisiting system paradigms from the viewpoint of manufacturing sustainability. Sustainability 3: 1323-1340.

Davidson CI, Hendrickson CT, Matthews HS, Bridges MW, Allen DT, Murphy CF, Allenby BR, Crittenden JC, Austin S (2010), Preparing future engineers for challenges of the $21^{\text {st }}$ Century: Sustainable Engineering Journal of Cleaner Production 18(7): 698-701.

Garbie IH (2012), Design for complexity: A global perspective through industrial enterprises analyst and designer. International Journal of Industrial and Systems Engineering 11(3): 279-307.

Garbie IH (2013), DFSME: Design for sustainable manufacturing enterprises (an economic viewpoint). International Journal of Production Research 51(2): 479-503.

Garbie IH (2014), An analytical technique to model and assess sustainable development index in manufacturing enterprises. International Journal of Production Research 52(16): 4876-4915.

Garbie IH (2015a), Sustainability awareness in industrial organizations. Procedia CIRP, 26: 64-69.

Garbie IH (2015b), Sustainability optimization in manufacturing enterprises. Procedia CIRP, 26: 504-509.

Garbie IH (2015c), Integrating sustainability assessments in the manufacturing enterprises. International Journal of Industrial and Systems Engineering 20(3): 343-368.

Garbie IH (2015d), Fundamental requirements for sustainability practices and implementation: an analytical modeling and empirical investigation. International Journal of Sustainable Manufacturing 3(4): 333-362.

Garbie IH, Parsaei HR, Leep HR (2008a), A novel approach for measuring agility in manufacturing firms. International Journal of Computer Applications in Technology 32(2): 95-103. 
Garbie IH, Parsaei HR, Leep HR (2008b), Measurement of needed reconfiguration level for manufacturing firms. International Journal of Agile Systems and Management 3(1-2): 78-92.

Garbie IH, Shikdar AA (2011a), Analysis and estimation of complexity level in industrial firms. International Journal of Industrial and Systems Engineering 8(2): 175-197.

Garbie IH, Shikdar AA (2011b), Complexity analysis of industrial organizations based on a perspective of systems engineering analysts. The Journal of Engineering Research (TJER) SQU 8(2): 19.

Glavic P, Lukman R (2007), Review of sustainability terms and their definitions. Journal of Cleaner Production 15: 1875-1885.

Garetti M, Taisch M (2012), Sustainable manufacturing: Trends and research challenges. Production Planning and Control 23(2-3): 83-104.

Hasna AM (2010), Sustainability classifications in engineering: discipline and approach. International Journal of Sustainable Engineering 3(4): 258-276.

Kulatunga AK, Jayatilaka PR, Jayawickrama M (2013), Drivers and barriers to implement sustainable concepts in Sri Lankan manufacturing sector. The $11^{\text {th }}$ Global Conference on Sustainable Manufacturing Berlin, Germany 177-182.

Labuschagne C, Brent AC, Erck RP (2005), Assessing the sustainability performances of industries. Journal of Cleaner Production 13: 373385.

Labuschagne C, Brent AC (2008), An industry perspective of the completeness and relevance of a social assessment framework for project and technology management in the manufacturing sector. Journal of Cleaner Production 19: 253-262.

Lee KH (2009), Why and how to adopt green management into business organization-The case study of Koren SMEs in manufacturing industry. Management Decisions 47(7): 1101-1121.

Leszczynska A (2012), Towards shareholders' value: An analysis of sustainability reports. Industrial Management and Data Systems 112(6): 911-928.

Liu S, Leat M, Smith MH (2011), State-of-the-art sustainability analysis methodologies for efficient decision support in green production operations. International Journal of Sustainable Engineering 4(3): 236-250.
Lozano R (2012), Towards better embedding sustainability into companies' systems: An analysis of voluntary corporate initiatives. Journal of Cleaner Production 25: 14-26.

Martins RA, Araujo JB, Ometto AR (2011), Investigation on use sustainability performance measures by Brazilian manufacturing companies. Proc. of the 2011 Industrial Engineering Research Conference, Institute of Industrial Engineers, May 21-25, 2011, Reno, NV, USA, 1121-1129.

Ron AJD (1998), Sustainable production: The ultimate result of a continuous improvement. International Journal of Production Economic 56-57: 99-110.

Rossen MA (2012), Engineering sustainability: A technical approach to sustainability. Sustainability 4: 2270-2292.

Rosen MA, Kishawy HA (2012), Sustainable manufacturing and design: Concepts, practices and needs. Sustainability 4: 154-174.

Theyel G, Hofmann K (2012), Stakeholder relations and sustainability practices of US small and medium-sized manufacturers. Management Research Review 35(12): 1110-1133.

Tseng ML, Divinagracia L, Divinagracia R (2009), Evaluating firm's sustainable production indicators in uncertainty. Computers and Industrial Engineering 57: 1393-1403.

Urban B, Naidoo R (2012), Business sustainability: Empirical evidence on operational skills in SMEs in South Africa. Journal of Small Business Enterprises Development 19(1): 146-163.

Veleva V, Hart M, Greiner T, Grumbley C (2001), Indictors of sustainable production. Journal of Cleaner Production 9(5): 447-452.

Veleva V, Ellenbecker M (2001), Indicators of sustainable production: Framework and methodology. Journal of Cleaner Production 9(6): 519-549.

Weiser CR, Vijayaraghavan A, Dornfeld D (2008), Metrics for sustainable manufacturing. Proceedings of the 2008 International Manufacturing Science and Engineering Conference (MSEC2008), Evanston, Illinois, USA, 1-9.

Winroth M, Almstrom P, Andersson C (2012), Sustainable indicators at factory level-A framework for practical assessment. Proceedings of the 2012 Industrial and Systems Engineering Research Conference New Orlando, Florida, USA.

World Commission on Environment and Development (WCED), (1987), Our Common Future. Oxford. UK: Oxford University Press. 